\title{
Analysis of Political Economy of Media Towards Women in Talkshow Television Program
}

\author{
Yousep Eka Irawan Apriyandi ${ }^{1}$, Umaimah Wahid ${ }^{2}$ \\ \{yusepekairaan@gmail.com ${ }^{1}$, umaimah.wahid@budiluhur.ac.id ${ }^{2}$ \} \\ Universitas Budi Luhur, Jl. Raya Cilediug Raya, Petukangan Utara, Jakarta Selatan-12260 \\ Indonesia $^{1,2}$
}

\begin{abstract}
This study aimed to explain and criticize women exploitation in mass media on television, particularly in reality show. Women often served as a capitalism commodity whom described as a fulfilment of the economic interests in media. The critical paradigm was used as a basis to examine and criticize women's reality as 'television media industry logic'. This research used Political Economy Theory of Media offered by Vincent Mosco including the commodification of content, audiences, and labors that concerned on concept of feminism which often views women as a tool of exploitation only in media business, particularly in television. The research method used was a case study regarding the technical media of feminist. The data was obtained by conducting interviews and observation from which could be criticized that media was still in ease to use 'women' as a form of media commodity as a fragile creature, but women today stayed survive and enjoyed such experience. Moreover, the audiences were also geared towards such shows because in which described 'the powerless women', the victim of a man's affair, and yet stayed great for being able to manage her patience for the sake of 'child'. While the commodification of labor had illustrated that television employees worked beyond the working hours and as the interests of media owners, especially when the program was in demand. Thus, as professional workers and had sufficient rational awareness, media workers remained subject to the interests of media owners and capital.
\end{abstract}

Keywords: Women, television-talkshow, political economy media-Vincent Mosco

\section{Introduction}

The world of television in Indonesia is growing rapidly, the rise of television stations makes viewers have many options to watch broadcast programs that suit their tastes. Television stations in every day provide a wide variety of programming programs, which are numerous and varied. This is in accordance with Syahputra (2013) that a media regime determines the gates in which information on cultural, social, economic, political and even religious issues will flow, then forming a discursive environment in which a topic is discussed, understood, believed, and responded [1]. Because the present capitalist system of media in Indonesia is also dominated by a group of bourgeoisie/ capitalist elite and the regime holder of media power. Thus, they are free in determining the construction of a particular reality for their sake.

The role or exposure of mass media to the community is enormous. Consciously or unconsciously, the community lifestyle has been controlled by mass media. Gamble and 
Gamble (2001 in Rachmat, 2000:14) state that a lot of people spend about seven hours to consume mass media amid busy work. Television is a visual audio medium that does not burden many conditions for the community to enjoy it. Based on its own function [2], television has three functions, namely: Information, Education, and Entertainment, convincing, changing and reinforcing attitudes), mobilizing political participation, anesthetizing functions and others [3].

Media becomes one of the exploitative spaces for women in the value of media capitalism on the one hand. On the other hand, the mass media, fully support the movement of women's emancipation that seen in the number of media, from electronic media and printed media featured female figures. Women seem to get their own place to explore and develop themselves in media. Women can be involved in all areas including in mass media, inseparable from the long struggle by women's movements in post-reformation to rise and gain their rights and freedom.

Women have found their right and freedom in the public sphere to actualize themselves and their thoughts. Also visible in the mass media, a lot of discussion about women about career and success with the life story of the winding. However, when media show a nice and inspirational look about women, it seems women have not get out of the public view as the traditional female figure in terms of domestic and physical.

Mass media has an important role in influencing the community. In the book Skills and Journalism, written by Adriana Venny (2006) in [4], he says that sits role as information media, education, and entertainment, the mass media also plays an important role in social, cultural, and economic life. The mass media today has indeed changed the view of women who are considered weak and always depend on men, thus become an independent figure and never give up. But it cannot be denied that women are still seeing as the object that attracts the audience through their physical form. Of the understanding, Thamrin Amal Tomagola in the Journal of Art Science and Design Ultimart Volume III Year 2011(Kuswandi, n.d.) describes women are considered as an interesting and profitable for business people in media industry to attract the attention of audiences and enhance the company's profits. The figure of women who are often displayed in mass media, such as frame, pillars, fusion, dishes, and association. Frames concerning biological beauty and charm, pillars as a household manager, sex related to affairs, dishes associated with the kitchen, and association for public affairs as a companion work environment.

The appearance of women according to Mansour Fakih in the book Gender Analysis and Social Transformation [6] which is concerned from the physical aspect in mass media is not seen clearly that women looked as an object that has a high selling value, because it has been mixed and has become the daily consumption of society in the market industry so people do not aware of it. Media as a market industry thathas very strong influence should pay attention to what should be contained in media for people consumption in various forms of programs, and one of which is talk show program.

Hitam Putihis a different talk show with other talk show programs. It is a program with Mind reading format where guest star will be made helpless when "bombarded" with questionsby the host of the show Deddy Corbuzier. Through this mind-reading talk show program, Hitam Putih also won Panasonic Global Award in 2011 and 2012. Havinga show host who is a Magician with his remarkable trademark, it is capable to influence others even reading their minds which makes this talk show program different from the others. The show time is on primetime or rest time, night at 19.00. It aims to provide information and entertainment for the audience. In addition to the interactive dialogue with the guests, one segment of the program also provides direct questions that unprepared before addressed by the 
host and the guests have to answer instantly which makes the unconsciously reveal their personal things.

At this time, the information program in the form of Talk Show has become such excellent programs on television. Not a single television station that does not broadcast a talk show program. This impression is in demand of audience. The talk show program is one of the most prominent television programs in attracting regular viewers that presented in light and entertaining or formal and serious. The talk show program is still trying to present information since the Law No. 32 Article 2002 paragraph 1 stipulates that a program of broadcast content must contain information, education, entertainment, and benefits for the establishment of intellect, character, morals, progress, nation power, maintaining unity, and practicing religious and cultural values of Indonesia.

Hitam Putih Talk show program is not one of the 7 Talk Show with the most number of viewers. However, according to Black and White host, Deddy Corbuzier, black and white program does not give priority to achieve a high rating but rather to be viral in social media and provide benefits both knowledge and information for the audience. In 2013 Hitam Putih program on Trans7 in 2013 ranked fifth from the top 10 popular talk show programs on private television with TVR (Television Rating) 2.0 and 9.8 share (source: AC Nielsen). The data shows at 2013 ,Hitam Putih is watched by $2 \%$ of television owners or $9.8 \%$ of television viewers in Indonesia [7].

Hitam Putih program leads the conversations on personal issues that are thought to be motivating and inspiring. The informants or invited guest stars will surely tell their experience in getting successtobe known by the public. The stories frequently make a guest speakers or guest stars cry. The questions are even straightforward to the guests. Content of this conversation is presented with casual packaging and some attractions, and even music. Personal problems from guest speakers or guests are considered interesting and good to be talking to the public.

Many violence occurs in women because of the developed and instilled of gender inequality in the patriarchal society. Patriarchy is an ideology that refers to gender differences which assume that men are superior to women. As an ideology, patriarchy is defined briefly as male power, the social relationship with which men rule. In the electronic media, especially television, such as on Hitam Putih show aired by Trans 7,people often watch the talk show that in stereotypes women viewed as emotional, irrational, and highly dependent creatures. In this case, the commodity of Nagita Slavina as a victim of the issue of her husband's affair, Raffi Ahmad with Ayu Ting Ting.

Based on the description in the background, the main problem raised in this study is women issue in Hitam Putih Talk show television program aired in Trans7 on April 17, 2017. The formula of the research problem was "How television media reflect women in perspective of political economy by Vincent Mosco in 'Hitam Putih' Talk Show Program on Trans7?

This research focused on women exploitation in media industry,particularly in television. The theme of women, their domestic life in entertainment world seem to be the content that appeals audience. Commodification is done by media workers to produce talks show content that able to inspire the 'sympathy' of audience, especially women. Women are part of social structure and tend to be placed as 'second position' in the household even though in reality it is not necessarily the case. But the concept of women and men has different values and positions in the structure of Indonesian life so it is very possible for a woman experienced injustice from the husband, family, and culture. It is part of the 'media capitalism' system that sells the reality of women as media consumption. 
Of course, women's disparity and discrimination are different and opposed by women based on their belief of feminism values. Feminists believe that women are able to resist and determine their reality in their awareness of the importance of that reality to women.

\subsection{Political Economy of Media by Vincent Mosco}

Vincent Mosco [8] in his book "The Political Economy of Communication: Rethinking and Renewal") mentioned that commodification is "the process of transforming use values into exchange values". Commodification is an attempt to change anything into a commodity or merchandise as a benefit. Commodification is related to how the process of transformation of goods or services with commodity value that has high economic value [9]. The practice of commodification is in accordance with the concept expressed by Vincent Mosco in his book The Political Economy of Communication of the media that marked by the change of content or media content into commodities to tearn profits. [8] Graham [10], mentions the use of advertisement is a refinement process of media commodification in economy.

Mosco [8] is the way capitalism carries out his aim to accumulate capital or realize value through the transformation of use value into exchange value. According to Mosco, a political economy approach is understood in the narrow and broad sense. In a narrow sense, a political economy approach means the study of social relations, particularly power relations, which together form the production, distribution and consumption of resources, especially communication resources. According Mosco [9], the process is widely political control because the process involves a social organization in a community. The study of political economy questions as well as explains the relationship of social, economic and politic, particularly power relations that are mutually formed for the production, distribution, and consumption of resources.

Wenerdha explains that based on the understanding of Vincent Mosco, commodification is an effort made by media to process media content in accordance with the wishes and interests of capitalism, which can be profitable. Commodification is done consciously on three elements: content, audience, and worker/labor. Commodification of media content is done by packing media impressions in such a way that it has economic value [11]. The economic value of media content is characterized by a program favored by audience. The audience is presented with show as if they needed it and important to them. As for the production process, labors are the power of the media to produce programs that appeal to the audience. Media workers are an integral part of the media industry determined by media owners.

\subsection{Feminism}

Etymologically, feminism is derived from the word femme (woman), which means female (single) who has a purpose to fight for the rights of their people (women in the plural sense), as a social class. So feminism is a woman's understanding that seeks to fight for her rights as a social class. In relation to this, it is necessary to distinguish between male and female with masculine and feminine. The concept of male and female is used to distinguish between biological and natural aspects, while masculine and feminine are used to distinguish between psychological and cultural aspects [12].

Feminism is not only related to emancipation problems that tend to be directly related to equality. Feminism also involves a renewal movement undertaken by men and women in an effort to expect a change in social status, culture, and worldview so as to achieve justice and 
equality of rights. With a more civilized language, it can be understood that feminism is a movement that demands the emancipation or equal rights and justice with men.

\subsection{Mass Media Industry}

The media in its operations aims at audiences and advertisers, the media markets the products to audiences and advertisers. Television broadcasts soap operas to be watched by the audience and for advertisers to advertise on the program. Audiences are people who consume products produced by the media. In the media world, the level, the magnitude, or the amount of a media can be seen from the number of people consuming the media. The level or large audience can be seen from ratings or shares of television and circulation for printed media, as well as viewers for online media. Advertisers are agencies or individuals who use media to inform or market their products. The output of advertisers as a market is revenue or income from advertising for a media [13].

In media industry, there are three types of media ownership: monopoly, oligopoly, and monopolistic competition. In the type of monopoly ownership, a media industry dominates the market. The type of monopolistic ownership usually occurs in authoritarian or communist countries in which the state has a monopolizing media and as a social institution, political, and propaganda tool, which not aiming for economic gain. TVRI in the era of authoritarianism of the New Order government had become a television station that dominates or monopolized "television industry" in Indonesia. The choice for audiences is only to "take it or leave it".

One of the media that popular for Indonesian people is television. Television is a tool of mass communication that functions as Surveillance, Interpretation, Linkage, Transmission of values, and Entertainment [14]. According to Morissan [15], television station is a very complex workplace involving many people with different types of expertise, cameras, image editors, reporters, graphic person, and other operational staff that must interact and communicate in order to produce the best possible broadcast.

Assessing television as a mass media is quite complicated in where a quality overlaps between media realities and the meaning of broadcasts in various interests. On the other hand, the more creative and savvy the producers of television broadcasts are, all kinds of broadcast programs will become news commodities. All news is something that can be commoditized. This is certainly in line with the notion of commodification as an extension of Marxist logic that describe television programs including news, movies, and other entertainments have the value of materials that can be sold [16].

According to John Fiske [16] television is as a cultural commodity. Fiske refers to a cultural economy in which the meaning and enjoyment circulated. According to him, in social culture the audience dismisses their role as a commodity and becomes a producer, producer of meaning and pleasure.

Along with the way of delivery process of the messages content in television media to the viewers, the message content will also be interpreted differently according to the vision of the viewers as well as the resulting effects are also diverse. Ideally, television as other mass media serves as an information tool, entertainment, social control, and geographical area linkage [5]. 


\section{Research Methodology}

In this study, the researcher use critical paradigm. Paradigm is the basic orientation for theory and research. In general, a scientific paradigm is the whole system of thinking. The paradigm consists of basic assumptions, research techniques, and examples of a good research techniques should be.

Guba \& Lincoln [17] also compile some paradigms in communication science theory. The paradigm proposed consists of positivistic paradigm, post positivism paradigm, critical paradigm, and constructivism paradigm. Some methodologists in social science field argue that positivistic and post positivism paradigms are a unity of paradigms, often called as classical paradigms. The methodological and technical implications of the two paradigms, in practice, do not have much difference. The existence of the paradigm constellation above the theories and the usual research grouped in three main paradigms, namely the classical paradigm, the critical paradigm, and the constructivism paradigm.

In this study, the researcher wanted to know more deeply about the position of women in talk show program in television media industry through "Hitam Putih" program on Trans 7 , therefore this research uses qualitative approach.

According to Djunaidi Ghony [18] qualitative research is a study that produces discoveries that cannot be achieved by using statistical procedures or by means of quantification. Qualitative research is explored and deepened from social phenomena or social environment consisting of behavior, events, places, and time. The social background is described in such a way which in conducting qualitative research, it develops the basic question: what and how it happened, who was involved, and where it occurred [18]. The method used in this research is case study method, which describes that case study is an approach to studying, explaining, or interpreting a case in its context naturally without any intervention from outsiders [19].

Case study is a research method that specifically investigates contemporary phenomena contained in a real-life context, implemented when the boundaries between phenomena and the context are unclear, using various data sources. Case studies reveal very detailed things, see through the things that cannot be expressed by other methods, and grasp the meaning that is behind the back of the object in a natural state [20].

In the book Qualitative Inquiry and Research Design: Choosing among Five Traditionswritten by Creswell (1998), it also explains several characteristics of a case study:

1. Identify the "case" for a study.

2. The case is a "system bound" by time and place.

3. Case studies use various sources of information in their data collection to provide a detailed and in-depth description of the event response.

4. Using a case study approach, the researcher will spend time in describing the context and setting for a case.

Meanwhile, Yin (2012) divided the general case study research into two types, namely case study research using single and plural cases or more. In addition, he also classifies it based on the number of unit analysis, holistic case study research using unit of analysis and embedded case study research using multiple units of analysis. The case study is called embedded, because it is tied to its predefined analytical units. The unit of analysis itself is needed to get more focus on its research purpose and objectives. Determination of unit analysis is determined through theoretical framework. Meanwhile, in holistic case study, the research conducted is more freely and focused on the case study and not tied to the unit of analysis as it fused in the case itself. If it is related to those ways of grouping, then the types of 
case study research can be arranged into a 2 x 2 matrix [19]. Thus, according to Yin (2012) case study research may consist of 4 (four) types. For more details of the relationship between the two groupings, it can be seen from the matrix images as follows:

The subject of this research is the Executive Producer, the Producer, and the Creative of Hitam Putih, and the Host. The research subject is determined through purposive sampling technique [19]. This technique includes people who are selected on the basis of certain criteria made by researchers based on research objectives [21]: In this study, the interview is questioning to:

1. Sisca Hormansyah as Executive Producer of Hitam Putih program.

2. Jovita Lupi as Producer of Hitam Putih.

3. Christina Ari as Senior Creative of Hitam Putih.

4. Deddy Corbuzier as Hitam Putih Host.

In the interview process, the researchers adjust the time with the speakers, for instances with Sisca Hormansyah, the production process of Hitam Putih talk show is done at night, and with Producer Jovita Lupi who is in tight time due to her dense activity. This becomes an obstacle for the researcher. However, this does not reduce the quality of the results data obtained in the interview.

Data collection in a research is an essential thing. In qualitative research, a researcher becomes the main instrument to search data by interacting symbolically with the informant or subject to be studied [18]. Primary data is obtained directly from the field. The primary data collection method is observation, interview, and documentation.

The purpose of these methods is to obtain information that supports the analysis and interpretation of data during the analysis. The research was conducted on production process in Editorial Room of Hitam Putih and Studio 9 Trans 7 in Trans Corp Area, Jl. Kapten Tendean Lot 12-14 South Jakarta, Indonesia. The study took place in June 2017.

\section{Result and Discussion}

Hitam Putih talk show is divided into four segments including one segment containing a Gimmick between the Presenters (Deddy Corbuzier) with Co. Host (Chika Jessika) inupdating hot news that is happening in society while added with silly comments from Deddy Corbuzier. In this early segment, it also displayed viral footage video news taken from Youtube and social media.

In analyzing the commodification of women in Hitam Putih talk show in Trans 7 which aired on April 18, 2017, the researchers will use the concept of commodification by Vincent Mosco, as follows.

\subsection{Commodification of Content}

One form of commodification in communication is the commodification of media content. This commodification of media content to be analyzed is a change of message from a set of data to the system of meaning in the form of marketable products. There is an exchange rate from the content creation process in a media product that results from social relationships between workers, consumers and owners of capital. Content commodification see through everything thatcan serve as a commodity whichmay enrich media owners. Audience is not 
aware when dictated about the offerings given by media companies as they feel the need to be entertained, so the media commoditize the content in order to compete and gain profit.

The commodification process of content or media content involves messages that changes from a data source to a system of thought and becomes a marketable product. Hitam Putih on Trans 7 is a talk show which also commands the content or the media content. Commodification occurred on Commodification of content or media content in Hitam Puth talk show was seen from the question and answer section between Nagita Slavina and Deddy Corbuzier which was personal interviews with private questions.

"According to Jovita Lupi, the concept of Hitam Putih is the question form that is made to be interesting without pushing the speakers, as it is for public consumption. Regarding this episode itself, the question is made very carefully than any other episode. For example, the interview starts with platitude, an interview with a cross question abouther son. As we want to dig deeper about something, the mood of the guest should be first built so it is not direct to the main point. At that time we know Nagita never wanted to be interviewed by any infotainment show about the case happened in her family. We are also made an agreement before the shooting. Nagita's side ask a list of questions that will be asked in advance so that she can choose and will answer which questions she approved.

As quoted above the researcher's interview via phone to the producer of Hitam Putih on April 18, 2017 with the theme of Curhatan Nagita Slavina (Nagita's Story), it was deliberately raised the theme of female's story through the answers on this episode. Moreover, the addition of speech-language pictures in this episode about her private life, Nagita was depicted as the victim of her husband's affair that tend to Close Up and Big Close Up so that the audience more interested in listening Nagita's story.

Hitam Putih producer is expected to display images that continue to focus on the guest face who is being plagued by the affair issue of her husband thus can give impact to the viewers to enjoy better episode show with the method of shooting Close Up and Big Close Up to the guest as the life story of women.

Commodity content or media content is also seen in the segment distribution, it was viewed from the Co Host and her appearance which suits the theme contained. In Hitam Putih, particularly in the Curhatan Nagita Slavina episode, the female role is highly visible to have been commoditized in content. Both Nagita as Subject and Object. This is seen from the interview withHitam Putih Producer, Lupita Jovi. It is said as the object because Nagita in this episode is described as the objectwho suffered from the affair issue of her husband. On the other hand, as the subject because Nagita herself has been willing to be a guest in Hitam Putih with a certain fee. This isa logical consequence in entertainment world as artists' personal life could not be hidden when emerged to mass media. Content Commodification of women does exist and is deliberately featured in Hitam Putih talk shows in which a concept created by creative team added spices in the questions to gain audience's interest in watching the talk show. From a capital point of view, the commodification of media content is influenced by the creation of surplus value or profit.

\subsection{Commodification of Audience}

Commodification of audiences in the media industry will affect the media products itself and implicate the extent to which advertisers are willing to spend money on them. It cannot be denied that today the media has become a colossal industry that is very important for the economy as does the manufacturing industry. The position of the audience becomes very important because it has great financial or economic potential. Audiences are beneficial to 
media owners, as well as indirectly paying wages or income to workers in the media industry and advertisers. The relationship between media, audiences, and advertisers is inevitable and becomes important in today mass media industry.

To see the relationship between media owners, audiences, and advertisers in the media industry, it can be reviewed through rating and share of a program that used as a measure of media owners and advertisers in achieving their goals. It also happens in Hitam Putih talk Show aired by Trans 7. In order to know whether the audiences also in part of commodification or not, the researchers conduct interviews with producers related to the level of sales and advertisers in Hitam Putih talk show.

The sales level is the main capital number of a successful media business in society. Besides, from which the advertisers will see their success in selling their products or ads. In Hitam Putih talk show, quoted from the Producer's interview stated that:

"In average,Hitam Putih Weekly Ratings and Share program is quite stable, especially when the story edition of Nagita Slavina which simply boosts the program share. Hitam Putih has been a talk show in Trans 7 for quite a while and was dropped, but because of public interest that wanted to return Hitam Putih show, it finally comes back now. Many people already know the success of this program, we also get a trophy in Panasonic Gobel Award. We could say that Hitam Putih still exist in the heart of loyal viewers".

From above explanation, it shows that Hitam Putih has a stable Rating and share level every week. The stable Ratings and Share is an indicator of advertisers in which decided to put ads on certain programs, which means audiences exist at the program. It is stated that the talk show in Indonesia is still much preferred by consumers who enjoy entertainment and information.

Other than displaying special guest episode in Hitam Putih to attract consumers and sales level, the content within not only oriented to audience but also to advertisers. Commodification of audiences in media industry will certainly be clearer when from the beginning to whom the program has found out. Mass audience is a privileged phenomenon in media relating to the huge number of people who read, hear, or watch the same product. The concept of audience is important, at least in terms of defining the material and assisting the sale. The quality information of which the audience obtained is another matter. Similarly, to the meaning and values of messages conveyed by media. In media industry, the quality and meaning of its products are often ignored. Media put forward the benefits to be gained profusely, especially from advertising revenue.

Media have large financial resources, as well as time and experience they use to make their words and images recognize and define the audience by conveying things that are relevant to a particular audience and bringing the audience into the material. In other words, there are interrelated relations between the product and the audience. Both are commoditized in such a way to benefit the media and advertising agencies.

In fact, the audience becomes a commodity marketed to advertisers in all mass media. Advertisers today do not just want the quantity of audiences, but they also need to know what types of audiences who will read, watch, or hear the content. These advertisers' interests, in practice, is responded to and well supported by media. Media construct audiences and content in such a way as to bring in advertisers.

This happens in Hitam Putih talk show that commoditizing his audience for profit. With the commodification of women as resource persons, as well as special editions by displaying many questions that exploit women, the level of sales has increased. Hitam Putih talk show attract consumers' attention by displaying women's issues as models which is interested by advertisers to place their products. Even the billing commitment of advertisers so that the ads 
continue to be placed in Hitam Putih talk show. This brings benefits to Trans 7 because the advertiser provides funds to the company for its next production.

\subsection{Commodification of Labor}

Media workers are often ignored by observers of media political economy. During this time, they tend to pay much attention to commodity content and audiences. Media owners know that workers are their assets in carrying out their duties. It was the optimal use of workers' minds and strength by constructing the minds to please them if they work in a media institution even within appropriate salary. It also happened to media worker in Trans 7 especially of Hitam Putih talk show. According to the informant who is also the producer of Hitam Putih, this is viewed from the working hours that is different from other companies, it is described as follows;

"The total working hours are twelve hours a day, the hours depend on the work load every day, if there is a shoot taping then it will be from seven in the morning until one at night, even if there is a preview 13shooting and only live editing, the team can be relaxed, work at eleven o'clock in the afternoon and go home at eleven at night depending on the condition, you know that working in TV does not provide any overtime money".

From the above explanation, it can be seen that the working time in Trans 7 especially Hitam Putih talk show is not the same as working hours of employees in general which should be counted eight hours from nine am to five pm. The shooting jobs until it is ready to be presented must be completed by the workers and it depends on some conditions. It is stated that, media workers are required to produce Hitam Putih talk show content for a specified time.

The condition is done by media owner to produce Hitam Putih talk show according to its daily run time. However, owners of media through their management has commoditized workers by providing comfort workspace which isin comfortable and informal atmosphere. In addition, there are some other advantages such as, internet access, free phones, as well as personal drivers for the access of media workers in producing Hitam Putih talk show. However, although the benefits or the salary given are also not worthto what they do, it is explained by the informant;

"Of benefit, the salary information is closed only to the employees themselves who know the nominal, for me personally, the salary I received, I think is not enough for my status. However, on the other hand I like my job and the environment here is not too formal that makes me feel comfortable. And most comfortable if our share reached the target, usually we get bonus, only if the target reached".

From the interview results above, it is stated that, even though their salary are not worth to what they worked in Hitam Putih talk show, because of their comfort and joy, it is their reason to stay with the company. Media owners and editors assign the tasks in substitute to the workers in producing material, one of which is to search and research the resource persons to be displayed in every show in Hitam Putih talk show.

Competition in media industry demands business players to commoditize something into a commodity. Media workers are required to accommodate what should be displayed to audiences with the aim at attracting audiences and benefiting from the sales level. At the same time, they have also been commoditized by media owners. According to Vincent Mosco, there is a tendency to ignore aspects of the commodification of workers and the production process. 
Workers are assumed to be no longer part of a unified concept, they are not designers of works, not even workforce.

Media workers have a dilemma in which the economy becomes an important factor in the movement of media work. It also happens to media workers in Hitam Putih talk show. Their skills and ability are needed to produce media content on TV shows. Seenfrom the results of informants as media workers in Hitam Putih talk show, the workers not only do the main job yet also do multitasking work. Therefore, Media owners try to make workers comfortable by providing support facilities. Also inHitam Putih talk show, the company provides facilities to support media workers in running the process in producing the talk show.

\section{Conclusion}

The occurrence of commodification at Hitam Putih Talk Show related to Political Economy of Media approach based on the commodification concept by Vincent Mosco was the attempt to turn anything into a commodity from value to an exchange rate.

a. The commodification of Content was occurred at Hitam Putih Talk Show that aired on April 18, 2017 that seen from a special segment which show personal interview ofone's personal life. In the segment, the guest women are performed in such a way to attract viewers' attention. Women are commoditized through shooting and also special in-depth interviews shown to bring viewers closer to the artist.

b. Commodification of Audience were conducted by the editor of Hitam Putih Talk Show in performing women in TV stations. Female guest are used as selling points to obtain sales level of Hitam Putih Talk Show that seen in the presence of advertisers who make billing commitment with Hitam Putih Talk Show.

c. The commodification of labor. Workers in Hitam Putih Talkshow had also been commoditized by media owners. It was seen in their job which they should be able to do multitasking to the main work and other work. Their skills and abilitywere used for successful production of Hitam Putih Talk Show.

\section{Acknowledgments}

Appreciation and gratitude to those who have supported this research and publication, that is; 1.) Master of Science Communication University of Budi Luhur. 2) Budi Luhur University and Budi Luhur Cakti Foundation. 3) Trans 7 TV and Producer of Hitam Putih Talk Show. 4). All Key Informants and Informants Research 


\section{References}

[1]I. Syahputra, Rezim Media: Pergulatan Demokrasi, Jurnalisme, dan Infotainment dalam Industri Televisi,. Jakarta: PT. Gramedia Pustaka Utama, 2013.

[2]N. Vera, Komunikasi Massa. Jakarta: PT. Ghalia Indonesia, 2016.

[3]Rizky Muhartia dan Riri Rinawati, "Instagram sebagai Media Komunikasi Pemasaran Grow Up."

[4]E. P. \& D. Karya, "Tindak Pidana Kekerasan Dalam Rumah Tangga Yang Dilakukan Suami Terhadap Istri (Studi Kasus Di Pengadilan Negeri Gresik),” J. Ilmu Huk., vol. Mei-Nope, pp. 81-92, 2014.

[5]W. Kuswandi, Komunikasi Massa: Analisis Interaktif Budaya Massa. Jakarta: Rineka Cipta.

[6]M. Fakih, Analisis Jender Dan Transformasi Sosial. Yogyakarta: Pustaka Pelajar, 2007.

[7]Kompasiana, "Inilah '10 Program Televisi Paling Hits' Sepanjang 2013," Kompasiana.com, Jakarta, 2013.

[8]V. Moscow, The Politicial Economy of Communication. london: Sage Publication, 2009.

[9]U. Wahid, "Media and commodification od Islamic Symbol in Political Campaig Toward General Election of governor/Vice Governor of DKI Jakarta 2017,” in ABESS 2917, 2017.

[10]A. Fachruddin, Cara Kreatif Mmeproduk Program Televisi. Yogyakarta: Penerbit Andi, 2015.

[11]I. Wenerdha, "Ekonomi Politik Vincent Mosco Oleh Media Online Entertaiment kapanlagi.com," journal.uad.ac.id, vol. Vol. 3. No, 2015.

[12]I. Mulyaningsih, "K.ajian Feminis Pada Novel Ronggeng Dukuh dan Berkalung Sorban,” J. Indones. Lang. Lit., vol. Vol. 1 No., 2015.

[13]T. Prahara, "download.portalgaruda.org/article.php?...KAJIAN\%20FEMINIS\%20PADA\%20NOV," vol. Volume 3, 2016.

[14]S. Susanti, S. Susanti, and I. Koswara, "Menyatukan Perbedaan melalui Seni Budaya Sunda," pp. 143-155, 2017.

[15]E. Ariadne, S. Dewi, F. I. Komunikasi, and U. Padjadjaran, "Konstruksi Makna Kandidat Politik Dalam Pemilu Kepala Daerah Bagi Masyarakat Kota Bandung ( Perspektif Komunikasi Politik ),” J. Ilmu Komun., vol. ISSN 2085, no. komunikais politik, pp. 87-97, 2017.

[16]G. Burton, Pengantar untuk Memahami: Meida dan Budaya Populer. Yogyakarta: Jalasutra, 2011.

[17]U. Wahid, "Political Communication and Social Change of Acehnese Societyin Internet Era," Adv. Sci. Lett. 22 (5-6), 1388-1392, vol. Mey - June, 2016.

[18]M. D. dan F. A. Ghony, Metode Penelitian Kualitatif. Yogyakarta: Ar-Ruzz Media, 2012.

[19]R. K. Yin, Studi Kasus,Desaid dan Methode. Jakarta: Raja Grafindo Persada, 2012.

[20]A. Salim, Teori dan Paradigma Penelitian Sosial. Yogyakarta: Tiara Wacana, 2006.

[21]R. Kriyantono, Teknik Praktis Riset Komunikasi. Jakarta: Kencana Prenada Media Group, 2006. 